\title{
Adipose tissue and the insulin resistance syndrome
}

\author{
Keith N. Frayn \\ Oxford Centre for Diabetes, Endocrinology and Metabolism, Radcliffe Infirmary, Oxford OX2 6HE, UK
}

\begin{abstract}
Obesity is associated with insulin resistance. Insulin resistance underlies a constellation of adverse metabolic and physiological changes (the insulin resistance syndrome) which is a strong risk factor for development of type 2 diabetes and CHD. The present article discusses how accumulation of triacylglycerol in adipocytes can lead to deterioration of the responsiveness of glucose metabolism in other tissues. Lipodystrophy, lack of adipose tissue, is also associated with insulin resistance. Any plausible explanation for the link between excess adipose tissue and insulin resistance needs to be able to account for this observation. Adipose tissue in obesity becomes refractory to suppression of fat mobilization by insulin, and also to the normal acute stimulatory effect of insulin on activation of lipoprotein lipase (involved in fat storage). The net effect is as though adipocytes are 'full up' and resisting further fat storage. Thus, in the postprandial period especially, there is an excess flux of circulating lipid metabolites that would normally have been 'absorbed' by adipose tissue. This situation leads to fat deposition in other tissues. Accumulation of triacylglycerol in skeletal muscles and in liver is associated with insulin resistance. In lipodystrophy there is insufficient adipose tissue to absorb the postprandial influx of fatty acids, so these fatty acids will again be directed to other tissues. This view of the link between adipose tissue and insulin resistance emphasises the important role of adipose tissue in 'buffering' the daily influx of dietary fat entering the circulation and preventing excessive exposure of other tissues to this influx.
\end{abstract}

Adipose tissue: Insulin resistance syndrome: Triacylglycerols

\section{Insulin resistance and adipose tissue}

Accumulation of adipose tissue, as in obesity, is associated with insulin resistance. A deficiency of adipose tissue, as in the condition of lipodystrophy, is also associated with insulin resistance. Is there one unifying explanation for these two seemingly paradoxical observations? The aim of the present paper is to provide such an explanation.

A brief introduction to the concept of insulin resistance is necessary in order to understand these observations. HP Himsworth, working at University College Hospital, London, UK, in the 1930s, was the first clearly to differentiate between the concepts of insulin secretion and insulin sensitivity (Himsworth, 1936). He found that some individuals with diabetes (typically lean individuals with an early onset of the disease) responded rapidly to an injection of insulin with a fall in blood glucose concentration. Other individuals, typically more obese and with later-onset diabetes, were resistant to the blood glucose-lowering effect of insulin. In the 1960s this concept was applied to non- diabetic but obese subjects whose metabolism was shown to be resistant to the effects of insulin (Rabinowitz \& Zierler, 1961) and who were found to have high levels of circulating insulin in response to glucose infusion (Karam et al. 1963). Since that time it has been recognised that sensitivity to insulin is related to body fat content, even within relatively normal ranges of BMI (Insel et al. 1975; Bogardus et al. 1985). In studies of large numbers of healthy individuals, it has been claimed that 'at BMI $>30 \mathrm{~kg} / \mathrm{m}^{2}$, nearly all subjects had a low insulin sensitivity index' (Clausen et al. 1996).

It is important to note that insulin resistance has been discussed so far only in terms of its effects on glucose metabolism. Most methods for assessing insulin resistance measure some combination of the ability of insulin to stimulate peripheral glucose disposal (mostly into muscle glycogen) and to suppress hepatic glucose production. Gerald Reaven (1988) proposed that insulin resistance could be seen as the centre of a constellation of changes that all adversely affect risk of cardiovascular disease (Table 1), a syndrome he suggested was common even amongst the 
Table 1. Characteristics of the insulin resistance syndrome based on the original description by Reaven, 1988; but this description has been expanded since by many authors, for example, see Landin et al. 1990, Jeppesen et al. 1995, Tooke \& Hannemann, 2000

\begin{tabular}{|c|c|}
\hline Phenotype & Significance \\
\hline $\begin{array}{l}\text { Glucose intolerance } \\
\text { Hyperinsulinaemia }\end{array}$ & Increase risk of type 2 diabetes mellitus \\
\hline $\begin{array}{l}\text { (Moderately) elevated fasting TG concentratio } \\
\text { Increased postprandial lipaemia } \\
\text { Reduced HDL-cholesterol concentration } \\
\text { Preponderance of small dense LDL particles } \\
\text { Hypertension } \\
\text { Impaired endothelial function } \\
\text { Procoagulant state }\end{array}$ & Increase risk of cardiovascular disease ( $\mathrm{CHD}$ and stroke) \\
\hline
\end{tabular}

TG, triacylglycerol.

apparently healthy population, and which he termed syndrome $\mathrm{X}$ (now more usually termed the insulin resistance syndrome or the metabolic syndrome). Reaven (1988) did not discuss obesity per se as part of this constellation, although now the insulin resistance syndrome is usually considered to include obesity, particularly of the abdominal variety.

The insulin resistance that accompanies obesity is also accompanied by these adverse changes in other systems. This factor is now accepted as the reason that obese individuals have a considerably increased risk of cardiovascular disease (Kaplan, 1989). Thus, we have to consider the mechanisms by which increasing fat storage in adipose tissue can lead to widespread changes in glucose and lipid metabolism, and other physiological systems including coagulation and blood pressure.

However, the situation is complicated by the fact that the disease of lipodystrophy, in which there is a deficiency of adipose tissue (either total or partial, usually involving loss of adipose tissue on the extremities), is also accompanied by insulin resistance and a high incidence of type 2 diabetes (Ganda, 2000). It would be satisfying to find an explanation that could unify these apparently contradictory observations.

\section{Possible links between adiposity and insulin resistance}

If increasing fat storage in adipose tissue is associated with increasing insulin resistance, the simplest explanation might be something like that shown in Fig. 1; adipose tissue releases some signal ('substance $X$ ' in Fig. 1) that affects muscle and liver glucose metabolism (since these are the metabolic variables measured as insulin resistance). That explanation does not seem unreasonable, but it is then difficult at first sight to see how we might reconcile this model with the observation of insulin resistance in lipodystrophy (Fig. 1(b)). I will return to this later (see p. 378).

Adipose tissue is now recognised as an important secretory organ (Spiegelman \& Flier, 1996; Mohamed-Ali et al. 1998), releasing into the circulation many peptides that affect metabolism, including of course the hormone leptin. Thus, there are many possible candidates for 'substance $\mathrm{X}$ '. Much attention has focused on the possibility that substance $\mathrm{X}$ is the cytokine, tumour necrosis factor (TNF)- $\alpha$ (Hotamisligil \& Spiegelman, 1994). However, there are

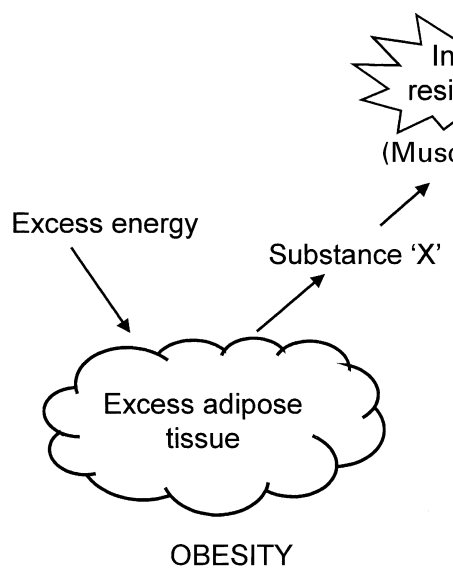

(a)

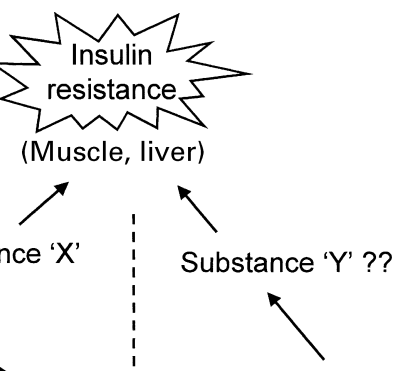

No adipose tissue

LIPODYSTROPHY

(b)
Fig. 1. (a) Schematic model for the association between obesity (excessive accumulation of triacylglycerol in adipose tissue) and insulin resistance of glucose metabolism, which is assessed in liver and skeletal muscle. The suggestion is that a substance ' $X$ ' signals from adipose tissue to these tissues. (b) Shows the apparent difficulty of extending this model to the link between deficiency of adipose tissue (lipodystrophy or lipoatrophy) and insulin resistance. It is not clear how absent adipose tissue can liberate a similar signal.

some difficulties with this concept (at least in human subjects). Studies of adipose tissue in vivo show that TNF- $\alpha$, although expressed in adipose tissue at increased levels in obesity (Hofmann et al. 1994), is not released into the circulation (Mohamed-Ali et al. 1997). Systemic TNF- $\alpha$ concentrations are not consistently related to obesity or insulin resistance (Hauner et al. 1998), and adipose tissue TNF- $\alpha$ expression is not correlated with insulin resistance except in morbid obesity (Koistinen et al. 2000). Taken together with evidence that TNF- $\alpha$ expression is also up regulated in other tissues such as skeletal muscle in insulin resistance (Saghizadeh et al. 1996), these observations seem to point to TNF- $\alpha$ as a paracrine mediator of insulin resistance (Hauner et al. 1998), but not as a systemic signal between adipose tissue and glucose-metabolizing tissues.

The most consistent evidence in favour of a candidate for substance $\mathrm{X}$ relates to fatty acids. (The general term fatty acids, rather than non-esterified fatty acids (NEFA), has been used for reasons expanded later.) J-P Flatt (1972) 
suggested such a link, reasoning that an increased mass of adipose tissue would deliver increased quantities of NEFA into the circulation. Increased plasma NEFA concentrations are a well-recognized feature of obesity (Opie \& Walfish, 1963). There have been many studies of the rate of NEFA turnover (production and utilization) in obesity, but some confusion as to their interpretation. A brief summary, based on a comprehensive study of NEFA turnover and its regulation by insulin (Campbell et al. 1994), is as follows. NEFA release from adipose tissue is suppressed by insulin in both lean and obese individuals, but in obesity the process is 'insulin resistant' in that the dose-response curve is shifted to the right. NEFA release per unit fat mass is actually less in obese subjects than in lean subjects (effectively, it is down regulated by the fasting hyperinsulinaemia). However, because of the increased fat mass, total NEFA delivery to the circulation is increased in obesity. Furthermore, if 'lean body mass' (including skeletal muscle and liver) is used as the denominator for NEFA turnover, then NEFA delivery to the consuming tissues is clearly increased in obesity. The 'insulin resistance' of adipose tissue lipolysis may be particularly relevant in relation to the delivery of NEFA in the postprandial period. Despite high plasma insulin concentrations in response to a standard mixed meal, obese subjects fail to suppress NEFA release from adipose tissue at a time when it is completely suppressed in lean subjects (Coppack et al. 1992).

The adverse effects of increased fatty acid availability on insulin sensitivity are well known. Since the early work by Randle et al. (1963) showing that increased availability of fatty acids will decrease glucose utilization in muscle, it has also been recognized that NEFA are a potent stimulus to hepatic glucose production (Ferrannini et al. 1983; Boden et al. 1994). In addition, elevated NEFA concentrations will acutely potentiate glucose-stimulated insulin secretion (Carpentier et al. 1999), although there is a longer-term 'lipotoxic' effect of fatty acids on the pancreatic $\beta$-cell that may be part of the link between obesity, insulin resistance and development of type 2 diabetes (Unger, 1995; Grill \& Qvigstad, 2000).

The increased flux of fatty acids from adipose tissue can be expanded beyond NEFA release. Since the enzyme lipoprotein lipase in adipose tissue is up regulated by insulin (Sadur \& Eckel, 1982; Farese et al. 1991), adipose tissue is an important site for the disposal of dietary triacylglycerol (TG; in the form of chylomicron-TG) in the postprandial period (Coppack et al. 1990). The process of TG-fatty acid uptake by adipose tissue may also become insulin-resistant in obesity. This process comprises two steps (Sniderman et al. 1997). The first step is the action of lipoprotein lipase on the chylomicron-TG. There are many demonstrations that acute insulin activation of adipose tissue lipoprotein lipase becomes 'insulin resistant' in obesity (Eckel, 1987; Ong \& Kern, 1989; Coppack et al. 1992). The second step involves the uptake of the fatty acids released by lipoprotein lipase into the adipocyte. The evidence here is less clear-cut, with some evidence for a reduction in this process in obesity (Coppack et al. 1992), but other evidence against such a reduction (Kalant et al. 2000). Nevertheless, on balance obesity is typically characterized by increased postprandial lipaemia (Coppack et al. 1992), reflecting at least in part prolonged residence of dietary fatty acids in the circulation (Lewis et al. 1990). These fatty acids, in the form of TG in remnant particles, will be removed by a number of tissues, including skeletal muscle and liver. Hence, again, in obesity the insulin-sensitive glucose-consuming tissues are subjected to an increased influx of fatty acids, and this increase is particularly marked in the postprandial period when adipose tissue, through 'insulin resistance', fails to protect other tissues from the influx of dietary fatty acids.

\section{Tissue triacylglycerol accumulation as a unifying feature}

Although the pioneering work of Randle et al. (1963) on the link between fatty acids and insulin sensitivity is often cited as pertaining to circulating NEFA, in fact their seminal paper clearly states that excess fatty acid availability may arise also from the local breakdown of tissue TG: "We suggest that there is a distinct biochemical syndrome ... due to breakdown of glycerides in adipose tissue and muscle, the symptoms of which are a high concentration of plasma NEFA, impaired sensitivity to insulin . . . . A unifying theory of insulin resistance in obesity that again focuses on the accumulation of tissue TG is now emerging from a large number of observations. Insulin resistance is associated with high levels of TG in skeletal muscle fibres (Phillips et al. 1996; Forouhi et al. 1999), liver (Banerji et al. 1995; Björntorp, 1995; Goto et al. 1995), and pancreatic islets (Koyama et al. 1997; Shimabukuro et al. 1997). Whilst there has been some debate about whether the accumulation of muscle TG is a cause or effect of insulin resistance, manipulation of tissue TG content in rodent models is associated with marked alterations in insulin sensitivity (Koyama et al. 1997; Shimabukuro et al. 1997). Accumulation of muscle TG may be accentuated by the defect in skeletal muscle fat oxidation observed in obese subjects (Blaak et al. 1994; Colberg et al. 1995).

A summary, then, is that in obesity the fat cells, perhaps because they are already 'overloaded' with TG, fail in their normal role of protecting other tissues from the daily influx of dietary fatty acids. The increased flux of fatty acids (both as NEFA and TG) in the circulation has acute adverse effects on insulin sensitivity, but also leads in the longer term to accumulation of TG in glucose-metabolizing tissues such as skeletal muscle, liver and the pancreatic $\beta$-cell. Accumulation of TG in these tissues, by some unknown mechanism, but probably involving local TG hydrolysis and availability of fatty acids or fatty acyl-CoA (Ellis et al. 2000), leads to an impairment of the normal sensitivity of glucose metabolism to insulin (or, in the case of the $\beta$-cell, to an impairment of insulin secretion in response to glucose). This view is, I believe, consistent with a large number of disparate observations in human subjects and experimental animals. It confirms the view that adipose tissue is a highly-active closely-regulated metabolic tissue that performs the vital role of buffering fluxes of fatty acids in the circulation in the face of variable input of dietary fatty acids from hour to hour. When eventually its buffering capacity is overwhelmed by consistent intake of fat above the rate of oxidation, the dietary fat has to go elsewhere, and its deposition in other tissues leads to insulin resistance. 
It might be noted that insulin resistance in general leads to fat oxidation at the expense of glucose. Insulin resistance is associated with diminished glucose utilization at a given insulin concentration (by definition) and failure to suppress NEFA release from adipose tissue. It is also associated with impaired activation of adipose tissue lipoprotein lipase by insulin (discussed earlier) and therefore generally with a partitioning of fatty acids towards oxidative tissues such as muscle. This situation leads to the idea that insulin resistance may even be seen as a metabolic adaptation to increasing obesity (Flatt, 1988; Frayn et al. 1991; Eckel, 1992). However, as will be discussed later, insulin resistance is clearly maladaptive in terms of the risk it confers of other chronic diseases.

We are left then with the question of why insulin resistance is also a feature of the lack of adipose tissue in lipodystrophy. Human lipodystrophy is relatively rare, and detailed metabolic studies are infrequent, although there has been success recently in identifying the genetic mutations involved in some forms of lipodystrophy (Cao \& Hegele, 2000; Shackleton et al. 2000). (The genes identified the code for nuclear envelope proteins, so this finding is not informative in terms of understanding insulin resistance.) This condition has been thoroughly investigated, however, in rodent models. Several mouse models have been created that lack adipose tissue wholly or partially. In one of the most severe models, the A-ZIP/F-1 mouse, the mice lacking adipose tissue are diabetic and severely insulin resistant, and have a twofold elevation of TG content in liver and skeletal muscle (Kim et al. 2000). Surgical transplantation of normal adipose tissue under the skin of these animals produces adipose tissue depots that become normally vascularized. Transplantation of adipose tissue reduces the TG content in liver and skeletal muscle, and reverses the insulin resistance and diabetes, in a dose-dependent manner; transplantation of normal physiological amounts is required to completely normalise the insulin responsiveness (Gavrilova et al. 2000; Kim et al. 2000). The effect of lipodystrophy has been described as 'alteration in the partitioning of fat between the adipocyte and muscle/liver leading to accumulation of $\mathrm{TG}$ in the latter tissues with subsequent impairment of insulin signalling and action' (Kim et al. 2000).

These results are, of course, completely in accord with the view put forward earlier, that the normal role of adipose tissue is to 'buffer' the daily influx of dietary fat entering the circulation (Fig. 2). If adipose tissue is overloaded, as in obesity, this buffering capacity is lost and other tissues are exposed to an excessive influx of fatty acids. If there is a deficiency of adipose tissue, as in lipodystrophy, then again this normal buffering action of adipose tissue is deficient (or absent) and other tissues are again exposed to an excessive flux of fatty acids. The result is accumulation of fatty acids in the form of TG in other tissues and interference with insulin-mediated glucose disposal (or glucose-stimulated insulin secretion, in the case of the $\beta$-cell).

One caveat to this unifying view needs to be expressed. There is powerful experimental evidence for another view of the insulin resistance of lipodystrophy, that it reflects leptin deficiency. Re-establishment of leptin expression in mouse models lacking adipose tissue can also normalize many metabolic variables including insulin resistance and tissue TG content (Koyama et al. 1997; Shimabukuro et al. 1997). However, the existence of leptin without adipose tissue is not a physiological situation and, furthermore, this model does not help explain the link between human obesity (a condition in which leptin concentrations are almost universally elevated; Considine et al. 1996) and insulin resistance. Nevertheless, this observation does add to our understanding of the normal vital role of adipose tissue in maintaining energy homeostasis through multiple mechanisms.

\section{Other adipose tissue components of the insulin resistance syndrome}

The point was made earlier that insulin resistance means more than just insensitivity of glucose metabolism to insulin. It affects lipid metabolism and is also associated with hypertension, endothelial dysfunction and adverse effects on other physiological systems. It is not my intention to discuss these other effects of insulin resistance here, since their pathogenesis has been covered in many reviews (Frayn, 1993; Björntorp, 1994; Brunzell \& Hokanson, 1999). However, it is interesting to note that again adipose tissue can be seen to play an important role, especially in the dyslipidaemia associated with insulin resistance, which may stem largely from impaired postprandial coordination of lipid metabolism (Patsch et al. 1984; Miesenböck \& Patsch, 1992; Frayn, 1993). Recent evidence that elevated NEFA concentrations can impair endothelial function (Steinberg et al. 1997, 2000; Lind et al. 2000) provides yet another link between adipose tissue function and components of the insulin resistance syndrome.

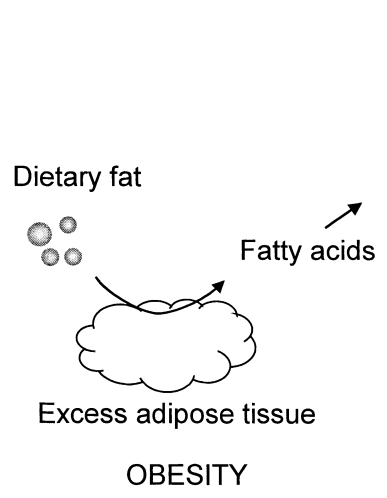

(a)

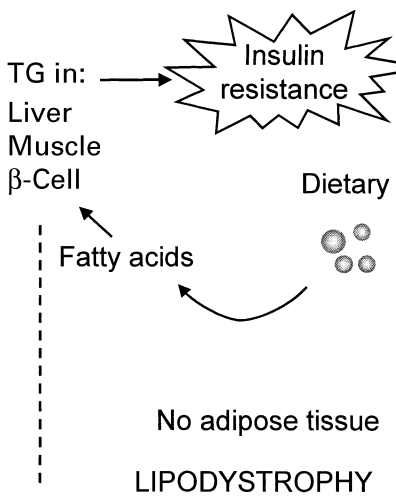

(b)
Fig. 2. A model that explains both $a$ and $b$ of Fig. 1. Loss of the normal 'buffering' effect of adipose tissue against the daily influx of dietary fat into the circulation in both obesity (when the fat cells are effectively overloaded) and lipodystrophy (when the adipose tissue necessary to perform such a function is lacking) leads to an excessive flux of fatty acids (both non-esterified fatty acids and triacylglycerol (TG)) into the circulation. This excess is deposited as TG in other tissues where it interferes with insulin responsiveness (liver and skeletal muscle) or with glucose-stimulated insulin secretion (pancreatic $\beta$-cell). 


\section{Acknowledgements}

I warmly thank my many colleagues in the Oxford Lipid Metabolism Group who have helped me to shape these views. I also thank our many collaborators, especially Peter Arner, Katherine Cianflone and Allan Sniderman who have provided valuable experimental insights.

\section{References}

Banerji MA, Buckley MC, Chaiken RL, Gordon D, Lebovitz HE \& Kral JG (1995) Liver fat, serum triglycerides and visceral adipose tissue in insulin-sensitive and insulin-resistant black men with NIDDM. International Journal of Obesity 19, 846-850.

Björntorp P (1994) Fatty acids, hyperinsulinemia, and insulin resistance: which comes first? Current Opinion in Lipidology $\mathbf{5}$, 166-174.

Björntorp P (1995) Liver triglycerides and metabolism. International Journal of Obesity 19, 839-840.

Blaak EE, Van Baak MA, Kemerink GJ, Pakbiers MT, Heidendal GA \& Saris WH (1994) $\beta$-adrenergic stimulation of energy expenditure and forearm skeletal muscle metabolism in lean and obese men. American Journal of Physiology 267, E306-E315.

Boden G, Chen X, Ruiz J, White JV \& Rossetti L (1994) Mechanisms of fatty acid-induced inhibition of glucose uptake. Journal of Clinical Investigation 93, 2438-2446.

Bogardus C, Lillioja S, Mott DM, Hollenbeck C \& Reaven G (1985) Relationship between degree of obesity and in vivo insulin action in man. American Journal of Physiology 248, E286-E291.

Brunzell JD \& Hokanson JE (1999) Dyslipidemia of central obesity and insulin resistance. Diabetes Care 22, Suppl. 3, C10-C13.

Campbell PJ, Carlson MG \& Nurjhan N (1994) Fat metabolism in human obesity. American Journal of Physiology 266, E600-E605.

Cao H \& Hegele RA (2000) Nuclear lamin A/C R482Q mutation in Canadian kindreds with Dunnigan-type familial partial lipodystrophy. Human and Molecular Genetics 9, 109-112.

Carpentier A, Mittelman SD, Lamarche B, Bergman RN, Giacca A \& Lewis GF (1999) Acute enhancement of insulin secretion by FFA in humans is lost with prolonged FFA elevation. American Journal of Physiology 276, E1055-E1066.

Clausen JO, Borch-Johnsen K, Ibsen H, Bergman RN, Hougaard P, Winther K \& Pedersen O (1996) Insulin sensitivity index, acute insulin response, and glucose effectiveness in a population-based sample of 380 young healthy Caucasians. Analysis of the impact of gender, body fat, physical fitness, and life-style factors. Journal of Clinical Investigation 98, 1195-1209.

Colberg SR, Simoneau J-A, Thaete FL \& Kelley DE (1995) Skeletal muscle utilization of free fatty acids in women with visceral obesity. Journal of Clinical Investigation 95, $1846-1853$.

Considine RV, Sinha MK, Heiman ML, Kriauciunas A, Stephens TW, Nyce MR, Ohannesian JP, Marco CC, McKee LJ, Bauer TL \& Caro JF (1996) Serum immunoreactive-leptin concentrations in normal-weight and obese humans. New England Journal of Medicine 334, 292-295.

Coppack SW, Evans RD, Fisher RM, Frayn KN, Gibbons GF, Humphreys SM, Kirk MJ, Potts JL \& Hockaday TDR (1992) Adipose tissue metabolism in obesity: lipase action in vivo before and after a mixed meal. Metabolism 41, 264-272.

Coppack SW, Fisher RM, Gibbons GF, Humphreys SM, McDonough MJ, Potts JL \& Frayn KN (1990) Postprandial substrate deposition in human forearm and adipose tissues in vivo. Clinical Science 79, 339-348.
Eckel RH (1987) Adipose tissue lipoprotein lipase. In Lipoprotein Lipase, pp. 79-132 [J Borensztajn, editor]. Chicago, IL: Evener.

Eckel RH (1992) Insulin resistance: an adaptation for weight maintenance. Lancet 340, 1452-1453.

Ellis BA, Poynten A, Lowy AJ, Furler SM, Chisholm DJ, Kraegen EW \& Cooney GJ (2000) Long-chain acyl-CoA esters as indicators of lipid metabolism and insulin sensitivity in rat and human muscle. American Journal of Physiology 279, E554-E560.

Farese RV, Yost TJ \& Eckel RH (1991) Tissue-specific regulation of lipoprotein lipase activity by insulin/glucose in normal-weight humans. Metabolism 40, 214-216.

Ferrannini E, Barrett EJ, Bevilacqua S \& DeFronzo RA (1983) Effect of fatty acids on glucose production and utilization in man. Journal of Clinical Investigation 72, 1737-1747.

Flatt J-P (1972) Role of the increased adipose tissue mass in the apparent insulin insensitivity of obesity. American Journal of Clinical Nutrition 25, 1189-1192.

Flatt JP (1988) Importance of nutrient balance in body weight regulation. Diabetes/Metabolism Reviews 4, 571-581.

Forouhi NG, Jenkinson G, Thomas EL, Mullick S, Mierisova S, Bhonsle U, McKeigue PM \& Bell JD (1999) Relation of triglyceride stores in skeletal muscle cells to central obesity and insulin sensitivity in European and South Asian men. Diabetologia 42, 932-935.

Frayn KN (1993) Insulin resistance and lipid metabolism. Current Opinion in Lipidology 4, 197-204.

Frayn KN, Coppack SW, Humphreys SM, Fisher RM \& Allman RFC (1991) Adipose tissue insulin resistance in obesity: protective mechanism or risk factor for heart disease? International Journal of Obesity 15, Suppl. 1, 55 Abstr.

Ganda OP (2000) Lipoatrophy, lipodystrophy, and insulin resistance. Annals of Internal Medicine 133, 304-306.

Gavrilova O, Marcus Samuels B, Graham D, Kim JK, Shulman GI, Castle AL, Vinson C, Eckhaus M \& Reitman ML (2000) Surgical implantation of adipose tissue reverses diabetes in lipoatrophic mice. Journal of Clinical Investigation $\mathbf{1 0 5}$, 271-278.

Goto T, Onuma T, Takebe K \& Kral JG (1995) The influence of fatty liver on insulin clearance and insulin resistance in nondiabetic Japanese subjects. International Journal of Obesity 19, 841-845.

Grill V \& Qvigstad E (2000) Fatty acids and insulin secretion. British Journal of Nutrition 83, Suppl. 1, S79-S84.

Hauner H, Bender M, Haastert B \& Hube F (1998) Plasma concentrations of soluble TNF-alpha receptors in obese subjects. International Journal of Obesity 22, 1239-1243.

Himsworth HP (1936) Diabetes mellitus. Its differentiation into insulin-sensitive and insulin-insensitive types. Lancet $\mathbf{i}$, $127-130$.

Hofmann C, Lorenz K, Braithwaite SS, Colca JR, Palazuk BJ, Hotamisligil GS \& Spiegelman BM (1994) Altered gene expression for tumor necrosis factor-alpha and its receptors during drug and dietary modulation of insulin resistance. Endocrinology 134, 264-270.

Hotamisligil GS \& Spiegelman BM (1994) Tumor necrosis factor alpha: a key component of the obesity-diabetes link. Diabetes $\mathbf{4 3}$, 1271-1278.

Insel PA, Liljenquist JE, Tobin JD, Sherwin RS, Watkins P, Andres $R$ \& Berman M (1975) Insulin control of glucose metabolism in man. A new kinetic analysis. Journal of Clinical Investigation 55, 1057-1066.

Jeppesen J, Hollenbeck CB, Zhou M-Y, Coulston AM, Jones C, Chen Y-DI \& Reaven GM (1995) Relation between insulin resistance, hyperinsulinemia, postheparin plasma lipoprotein lipase activity, and postprandial lipemia. Arteriosclerosis, Thrombosis and Vascular Biology 15, 320-324. 
Kalant D, Phélis S, Fielding BA, Frayn KN, Cianflone K \& Sniderman AD (2001) Increased postprandial fatty acid trapping in subcutaneous adipose tissue in obese women. Journal of Lipid Research 41, 1963-1968.

Kaplan NM (1989) The deadly quartet. Upper-body obesity, glucose intolerance, hypertriglyceridemia, and hypertension. Archives of Internal Medicine 149, 1514-1520.

Karam JH, Grodsky GM \& Forsham PH (1963) Excessive insulin response to glucose in obese subjects as measured by immunochemical assay. Diabetes 12, 197-204.

Kim JK, Gavrilova O, Chen Y, Reitman ML \& Shulman GI (2000) Mechanism of insulin resistance in A-ZIP/F-1 fatless mice. Journal of Biological Chemistry 275, 8456-8460.

Koistinen HA, Bastard JP, Dusserre E, Ebeling P, Zegari N, Andreelli F, Jardel C, Donner M, Meyer L, Moulin P, Hainque B, Riou JP, Laville M, Koivisto VA \& Vidal H (2000) Subcutaneous adipose tissue expression of tumour necrosis factor- $\alpha$ is not associated with whole body insulin resistance in obese nondiabetic or in type-2 diabetic subjects. European Journal of Clinical Investigation 30, 302-310.

Koyama K, Chen G, Lee Y \& Unger RH (1997) Tissue triglycerides, insulin resistance, and insulin production: implications for hyperinsulinemia of obesity. American Journal of Physiology 273, E708-E713.

Landin K, Stigendal L, Eriksson E, Krotkiewski M, Risberg B, Tengborn L \& Smith U (1990) Abdominal obesity is associated with an impaired fibrinolytic activity and elevated plasminogen activator inhibitor-1. Metabolism 39, 1044-1048.

Lewis GFO, Meara NM, Soltys PA, Blackman JD, Iverius PH, Druetzler AF, Getz GS \& Polonsky KS (1990) Postprandial lipoprotein metabolism in normal and obese subjects: comparison after the vitamin A fat-loading test. Journal of Clinical Endocrinology and Metabolism 71, 1041-1050.

Lind L, Fugmann A, Branth S, Vessby B, Millgård J, Berne C \& Lithell $\mathrm{H}$ (2000) The impairment in endothelial function induced by non-esterified fatty acids can be reversed by insulin. Clinical Science 99, 169-174.

Miesenböck G \& Patsch JR (1992) Postprandial hyperlipidemia: the search for the atherogenic lipoprotein. Current Opinion in Lipidology 3, 196-201.

Mohamed-Ali V, Goodrick S, Rawesh A, Katz DR, Miles JM, Yudkin JS, Klein S \& Coppack SW (1997) Subcutaneous adipose tissue secretes interleukin-6 but not tumor necrosis factor- $\alpha$ in vivo. Journal of Clinical Endocrinology and Metabolism 82, 4196-4200.

Mohamed-Ali V, Pinkney JH \& Coppack SW (1998) Adipose tissue as an endocrine and paracrine organ. International Journal of Obesity 22, 1145-1158.

Ong JM \& Kern PA (1989) Effect of feeding and obesity on lipoprotein lipase activity, immunoreactive protein, and messenger RNA levels in human adipose tissue. Journal of Clinical Investigation 84, 305-311.

Opie LH \& Walfish PG (1963) Plasma free fatty acid concentrations in obesity. New England Journal of Medicine 268, 757-760.
Patsch JR, Prasad S, Gotto AMJ \& Bengtsson-Olivecrona G (1984) Postprandial lipemia. A key for the conversion of high density lipoprotein $_{2}$ into high density lipoprotein $_{3}$ by hepatic lipase. Journal of Clinical Investigation 74, 2017-2023.

Phillips DIW, Caddy S, Ilic V, Fielding BA, Frayn KN, Borthwick AC \& Taylor R (1996) Intramuscular triglyceride and muscle insulin sensitivity: evidence for a relationship in non-diabetic subjects. Metabolism 45, 947-950.

Rabinowitz D \& Zierler KL (1961) Forearm metabolism in obesity and its response to intra-arterial insulin. Evidence for adaptive hyperinsulinism. Lancet i, 690-692.

Randle PJ, Garland PB, Hales CN \& Newsholme EA (1963) The glucose-fatty acid cycle. Its role in insulin sensitivity and the metabolic disturbances of diabetes mellitus. Lancet i, 785-789.

Reaven GM (1988) Role of insulin resistance in human disease. Diabetes 37, 1595-1607.

Sadur CN \& Eckel RH (1982) Insulin stimulation of adipose tissue lipoprotein lipase. Use of the euglycemic clamp technique. Journal of Clinical Investigation 69, 1119-1125.

Saghizadeh M, Ong JM, Garvey WT, Henry RR \& Kern PA (1996) The expression of TNF $\alpha$ by human muscle. Relationship to insulin resistance. Journal of Clinical Investigation 97, 1111-1116.

Shackleton S, Lloyd DJ, Jackson SN, Evans R, Niermeijer MF, Singh BM, Schmidt H, Brabant G, Kumar S, Durrington PN, Gregory S, O'Rahilly S \& Trembath RC (2000) LMNA, encoding lamin $\mathrm{A} / \mathrm{C}$, is mutated in partial lipodystrophy. Nature Genetics 24, 153-156.

Shimabukuro M, Koyama K, Chen G, Wang M-Y, Trieu F, Lee Y, Newgard CB \& Unger RH (1997) Direct antidiabetic effect of leptin through triglyceride depletion of tissues. Proceedings of the National Academy of Sciences, USA 94, 4637-4641.

Sniderman AD, Cianflone K, Summers LKM, Fielding BA \& Frayn KN (1997) The acylation-stimulating protein pathway and regulation of postprandial metabolism. Proceedings of the Nutrition Society 56, 703-712.

Spiegelman BM \& Flier JS (1996) Adipogenesis and obesity: rounding out the big picture. Cell 87, 377-389.

Steinberg HO, Paradisi G, Hook G, Crowder K, Cronin J \& Baron AD (2000) Free fatty acid elevation impairs insulinmediated vasodilation and nitric oxide production. Diabetes 49 , 1231-1238.

Steinberg HO, Tarshoby M, Monestel R, Hook G, Cronin J, Johnson A, Bayazeed B \& Baron AD (1997) Elevated circulating free fatty acid levels impair endothelium-dependent vasodilation. Journal of Clinical Investigation 100, 1230-1239.

Tooke JE \& Hannemann MM (2000) Adverse endothelial function and the insulin resistance syndrome. Journal of Internal Medicine 247, 425-431.

Unger RH (1995) Lipotoxicity in the pathogenesis of obesitydependent NIDDM. Genetic and clinical implications. Diabetes 44, 863-870. 